\title{
Reducing Misconceptions of Elementary School Students Through Guided Inquiry Learning
}

\author{
I Gede Margunayasa ${ }^{1}$, Nyoman Dantes ${ }^{2}$, A. A. I. N. Marhaeni ${ }^{3}$, I Wayan Suastra ${ }^{4}$ \\ 1,2,3,4 Universitas Pendidikan Ganesha, Singaraja, Indonesia
}

\section{ART ICLE INFO}

Article history:

Received August 12, 2021

Revised August 15, 2021

Accepted October 16, 2021

Available online November 25, 2021

Kata Kunci:

inkuiri Terbimbing, Miskonsepsi, Sekolah Dasar

Keywords:

Guided Inquiry, Misconceptions, Elementary School

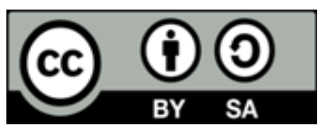

This is an open access article under the CC BY-SA license.

Copyright (C) 2021 by Author. Published by Universitas Pendidikan Ganesha.

\section{A B S T R A C T}

\section{A B S T RAK}

Beberapa siswa memiliki konsepsi mengenai konsep-konsep sebelum mereka mengikuti pelajaran di sekolah. Hal ini disebabkan karena kesalahpahaman siswa terhadap materi pembelajaran yang disampaikan oleh guru. Tujuan penelitian ini adalah menganalisis pengaruh model pembelajaran inkuiri terbimbing terhadap miskonsepsi siswa kelas lima di sekolah dasar. Jenis penelitian ini adalah penelitian eksperimen semu. Populasi penelitian ini berjumlah 43 siswa di sekolah dasar. Pemilihan sampel penelitian menggunakan multistage random sampling. Instrument yang digunakan untuk mengumpulkan data yaitu kuesioner. Teknik yang digunakan untuk mengumpulkan data yaitu dekriptif kualitatif dan kuantitatif. Hasil penelitian yaitu terdapat perbedaan yang signifikan miskonsepsi siswa antara kelompok siswa yang dibelajarkan dengan pembelajaran inkuiri terbimbing dan pembelajaran konvensional ( $F=7,447 ; p<0.05)$. Miskonsepsi pada siswa yang belajar dengan pembelajaran inkuiri terbimbing lebih rendah dibandingkan siswa yang belajar dengan pembelajaran konvensional. Implikasi penelitian ini yaitu pembelajaran inkuiri terbimbing dapat digunakan oleh guru dalam pembelajaran untuk mengatasi miskonsepsi pada siswa.

\begin{abstract}
Some students have a conception of the concepts before they attend school lessons. It is because students are interested in the learning material delivered by the teacher. This study aimed to analyze the effect of the guided inquiry learning model on the misconceptions of fifth graders in elementary schools. This type of research is quasi-experimental research. The population of this study amounted to 43 students in elementary schools. The research sample was selected using multistage random sampling. The instrument used to collect data is a questionnaire. The technique used to collect data is descriptive qualitative, and quantitative. The study results showed significant differences in students' misconceptions between groups of students who were taught with guided inquiry learning and conventional learning $(F=7,447 ; p<0,05)$. Misconceptions in students who learn with guided inquiry learning are lower than students who learn with conventional learning. This research implies that guided inquiry learning can be used by teachers in learning to overcome misconceptions in students.
\end{abstract}

\section{INTRODUCTION}

A teacher must distinguish between students who do not know the concept and students who have misconceptions. If the teacher cannot distinguish, it will be difficult for the teacher to find a solution to overcome students' misconceptions (Liu et al., 2020; Stellmacher et al., 2020). Besides that, it is also important for teachers to know students' misconceptions as input in designing learning (Bdiwi et al., 2019; Nurlaily et al., 2019). Conception is also termed as a person's embodiment or interpretation of an event or object. Because students themselves form their knowledge, it cannot be said that knowledge is wrong, but this knowledge is not by the views of experts and experts in their field (Agung, 2016; Mursalin, 2014). The results of the study stated that some students had conceptions of concepts before they took lessons at school (Adi \& Oktaviani, 2019; Mursalin, 2014). It is due to the students' misunderstanding of the learning material delivered by the teacher (Negor et al., 2018; Yunitasari et al., 2019). Learning science in Indonesia in primary schools has not improved students' inquiry skills much (Ertikanto et al., 2017; Muliani \& Wibawa, 2019).Other research also states that guided inquiry learning has increased the percentage of students who 
know concepts to 54\%, although there are still misconceptions by $35 \%$ of students (Fajarianingtyas \& Yuniastri, 2015). Students' concepts are their knowledge, built through informal processes in understanding everyday experiences and is called prior knowledge or preconceptions (Li et al., 2021; Meriana et al., 2021; Shrestha \& Jose, 2014). The students' preconceptions show that students' minds from birth are not silent but continue to be active to understand something. Children's minds continue to adjust to the situation they are experiencing to understand what they are experiencing in life.

One way that can be used to identify students' misconceptions is the CRI (Certainty of Response Index) method (Dede Trie Kurniawan \& Maryanti, 2018; Sadh et al., 2017). CRI is the level of confidence or certainty of respondents in answering each question item. Students with high CRI reflect high confidence or certainty of concepts in answering questions, while students with low CRI indicate that answers are only based on guesses (Mustika et al., 2015; Widarti et al., 2016). Thus, students who have misconceptions and those who do not know the concept easily distinguish between schools (Adi \& Oktaviani, 2019; Mursalin, 2014). Students who do not know the concept answer incorrectly with a low CRI, while students who have misconceptions answer incorrectly with a high CRI. According to the causal factors, misconceptions can be overcome by applying learning models/methods by the teacher. One of the learning models that can be used is guided inquiry learning (Gunawan et al., 2019; Husnaini \& Chen, 2019; Margunayasa et al., 2019). Guided inquiry learning emphasizes the discovery process. Guided inquiry learning can be interpreted as a teaching method that allows students to move step by step from problem identification, defining hypotheses, problem formulation, data collection, results in verification, and generalization to drawings towards conclusions (Anjelina \& Mawardi, 2021; Leonard \& Nwanekezi, 2018; Stender et al., 2018). The guided inquiry learning model has advantages so that it can reduce students' misconceptions. The advantage of the guided inquiry learning model is that it provides space for students to learn according to their cognitive style (Arantika et al., 2019; Pratono et al., 2018). In addition, this learning model can serve the needs of students who have above average abilities (Taruh et al., 2019; V. A. Wahyuni et al., 2019). The inquiry learning model is considered by the development of modern psychology, which considers learning as a process of change and can create meaningful learning because it develops cognitive, affective and psychomotor aspects in a balanced way (Ari Astuti et al., 2019; Kuala, 2020; Washington, 2019).

The position of inquiry learning in the curriculum is very strategic. Even in the 2013 curriculum, it is expressly stated that inquiry learning is one of the contextual learning models that can be used to support scientific approaches (Athanases et al., 2020; Santiasih et al., 2013). The findings of previous studies also state that guided inquiry learning can reduce students' misconceptions (Kohar et al., 2017; Witanecahya \& Jatmiko, 2014). It can be concluded that the inquiry learning model can reduce misconceptions in students. This study aimed to analyze the effect of the guided inquiry learning model on the misconceptions of fifthgrade elementary school students in Singaraja City on the light material. It is hoped that this learning model can help students in learning to reduce misconceptions in students.

\section{METHOD}

This type of research is quasi-experimental research. The research population is 43 public elementary schools in Singaraja City, Bali. The research sample was selected using multi-stage random sampling, consisting of 4 elementary schools $(n=60)$ for the experimental group and four elementary schools $(n=63)$ for the control group. The experimental group learns through guided inquiry learning, and the control group learns through conventional learning. Students' misconceptions data were collected using a science learning outcome test instrument on the nature of light material in the form of multiple-choice (reliability $=0.89$ ) with a grid-like Table 1 . Light material was chosen because the research results of Haslag and Concannon (2012) stated that many students have misconceptions about light when they are just starting to enter junior high school, and it is the teacher's responsibility to find activities that can reduce misconceptions/ideas.

Table 1. Grid of Science Learning Outcomes for Material Properties of Light

\begin{tabular}{lc}
\hline \multicolumn{1}{c}{ concept } & Question item number \\
\hline The nature of light travels in a straight line & $1,2,3,4$ \\
The nature of light penetrating clear objects & $5,6,7$ \\
Characteristics of the image formed by plane, concave, and convex mirrors & $8,9,10,11$ \\
The nature of light can undergo refraction & 12 \\
The nature of light can undergo decomposition. & 13,14 \\
\hline
\end{tabular}

The Certainty of Response Index (CRI) technique can identify students' misconceptions. CRI provides a measure of the level of certainty or level of confidence in answering each question. The measure 
of the level of confidence is expressed on a Likert scale. CRI was developed using a scale of six (0-5) (Hasan et al., 1999). When students answer each of the multiple-choice questions, students are asked to fill in the CRI level between 0 and 5. A scale of 0 states that students have no knowledge or total guesswork, while a scale of 5 states that students are very confident in their knowledge when answering.

\section{RESULT AND DISCUSSION}

\section{Result}

Based on the answers to each question and the level of CRI filled out by students, students can be categorized into lucky students or total guesses (TM), students who do not know the concept (TTK), students who know the concept (TK), and students who have misconceptions. (MK). Based on data analysis, the number of students for all indicators who experience misconceptions in the experimental group is 168 out of 840 (20\%), while in the control group, as many as 235 out of 882 (26.6\%). Most misconceptions occur in the material "the nature of the image formed by flat, concave, and convex mirrors", where the experimental group is $30.4 \%$, and the control group is $38.9 \%$. The least misconceptions occurred in the material "The nature of light propagates in a straight line" in the experimental group $6.3 \%$ and the control group 11.9\%. The guided inquiry learning model is effective in reducing students' misconceptions compared to conventional learning. Furthermore, the data on students who total guessed (TM), did not know the concept (TTK), knew the concept (TK), and misconceptions (MK) in the experimental group for all items. Based on the results of data analysis, it is known that the number of students in the experimental group who experienced the most misconceptions occurred in items number $8,10,11$, and 12 . At the same time, the number of students who experienced the least misconceptions was in items number 1 and 2 . Furthermore, the total student data was displayed. guess (TM), do not know the concept (TTK), know the concept (TK), and the misconception (MK) in the control group.

Based on the results of data analysis, the number of students in the control group who experienced the most misconceptions occurred in items number 7, 8, 9, 10, and 11. At the same time, the number of students who experienced the least misconceptions was in items number 1 and 2. prerequisite analysis through normality test and homogeneity of data distribution. Data distribution normality test using Kolmogorov-Smirnov test through SPSS 16.0 for the experimental group obtained a statistical value of 0.112 with a significance of 0.06 ( $p>0.05)$, and for the control group, a statistical value of 0.076 with a significance of 0.08 ( $p>0.05$ ) was obtained. ). The results of this test indicate that the data distribution of students' misconceptions in the experimental group and the control group is normally distributed. Furthermore, the results of the homogeneity test of misconception data through Levene Statistics show a statistical value of 1.949 with a significance of 0.165 ( $p>0.05)$. Hypothesis testing in this study was conducted by analysing variance through SPSS 16.0, obtaining an F value of 7.447 with a significance of $0.01(\mathrm{p}<0.05)$, which means the variance is homogeneous. These results indicate that the null hypothesis, which states "there is no difference in students' misconceptions between those who study with the guided inquiry model and those who learn with the conventional", is rejected. There are differences in students' misconceptions between those who study with a guided inquiry model and those who learn with conventional. The average misconceptions of students who study with the guided inquiry model are smaller than those of students who learn conventionally.

\section{Discussion}

The results showed that the guided inquiry learning model effectively reduced misconceptions experienced by students compared to conventional learning. The guided inquiry learning model provides a good atmosphere for creating student-centred learning (Suparmi, 2019; Suryantari et al., 2019). The inquiry learning model provides opportunities for more student-centred learning (Carlucy et al., 2018; Nurmayani et al., 2018).Student-centred learning allows students to be more involved in learning (Ruqoyyah et al., 2020; R. Wahyuni et al., 2017). The greater the involvement of students in the teaching and learning process, the greater their learning abilities and the effect on student learning outcomes (Fitriyati \& Munzil, 2017; Siagian \& Simatupang, 2017). By increasing student learning outcomes means that students experience misconceptions. Another thing will be very different if the learning applied is more teacher-centred. It can lead to less student involvement in learning (Bressington et al., 2018; Hwang et al., 2020). Little student involvement in learning certainly causes the learning to be less meaningful for students (Chai \& Kong, 2017; Clay et al., 2021). Less meaningful learning is one of the causes of students' misconceptions. Learning through discovery strongly supports student-centred learning. Through inquiry, it gives freedom to students by encouraging them to have a more active and responsible role in various stages of investigation (Angela, 2014; Chai \& Kong, 2017). Inquiry-based learning places special emphasis on cognitive learning and discovery and the goal of developing higher-order thinking (Brown et al., 2021; Pratiwi et al., 2016). 
The inquiry learning model is recommended for learning through discovery. In other words, the teacher does not teach everything directly or explicitly.

Learners are expected and encouraged to discover knowledge, generate rules based on a series of activities, and better apply these rules or knowledge to new cases and deal with everyday life situations (Anjelina \& Mawardi, 2021; Febriana et al., 2018; Kuala, 2020). Thus, misconceptions will not occur during the learning process. Through this learning, students can know and find the correct concept (Cooper et al., 2020; Laksana et al., 2019). In inquiry learning, the teacher becomes a facilitator to help students explore and find concepts to make learning more challenging. The advantages of inquiry learning are allowing students to think, thinking carefully, creating space for students to participate fully to increase curiosity (Kusumah et al., 2020; Purwanita et al., 2019). It certainly can improve understanding of processes, concepts and relationships between concepts and keep students' misconceptions away. The findings of previous studies also state that the inquiry learning model can improve student learning outcomes (Rosidin et al., 2019; Tan, 2021; Taruh et al., 2019). The guided inquiry learning model is very relevant to be applied to elementary school students. However, in general, the principles of conducting guided inquiry are no different from other inquiry forms. The word "guided" only means that elementary school students must be guided when carrying out activities, not left to do activities. It is done with the aim of students being able to achieve their goals by minimizing errors. If this can be achieved, then it will be a big capital to carry out other inquiries. The word "guided" also does not mean that everything is based on teacher guidance, but little by little, the guidance will be reduced so that students can carry out modified inquiries and even open inquiries one day.

\section{CONCLUSION}

Guided inquiry learning is effective in reducing students' misconceptions compared to conventional learning. Guided inquiry learning steps allow students to act as experts in finding concepts. Teachers can use guided inquiry learning in overcoming misconceptions experienced by students. However, before learning begins, the teacher should first identify the misconceptions experienced by students. Teachers can use the CRI method to identify students' misconceptions.

\section{REFERENCES}

Adi, Y. K., \& Oktaviani, N. M. (2019). Faktor-Faktor Penyebab Miskonsepsi Siswa SD pada Materi Life Processes and Living Things. Profesi Pendidikan Dasar, 6(1). https: //doi.org/10.23917/ppd.v6i1.7988.

Agung, I. (2016). Penerapan Sistem Neuro Associative Conditioning (NAC) pada Guru sebagai Upaya Meningkatkan Mutu Pendidikan. Jurnal Pendidikan Dan Kebudayaan, 19(2). https://doi.org/10.24832/jpnk.v19i2.287.

Angela, T. (2014). Challenges to Meaningful Learning in Social Studies - The Key Competences as an Opportunity to Students' Active Participation. Procedia - Social and Behavioral Sciences, 128, 192197. https://doi.org/10.1016/j.sbspro.2014.03.142.

Anjelina, Y., \& Mawardi, M. (2021). Validity of Flipped Classroom Based on Guided Inquiry in Chemical Bonding Materials Using Edmodo. International Journal of Progressive Sciences and Technologies, 27(1), 29-34. https://doi.org/10.52155/ijpsat.v27.1.3023.

Arantika, J., Saputro, S., \& Mulayani, S. (2019). Effectiveness of guided inquiry-based module to improve science process skills Effectiveness of guided inquiry-based module to improve science process skills. International Conference on Mathematics and Science Education, 0-6. https: //doi.org/10.1088/1742-6596/1157/4/042019.

Ari Astuti, E., Wardani, S., \& Kadarwati, S. (2019). The effectiveness of practicum-based worksheet based on salt hydrolysis material viewed from the aspect of laboratory skills and interpersonal intelligence learners. Journal of Education and Learning (EduLearn), 13(4), 502-509. https: //doi.org/10.11591/edulearn.v13i4.12397.

Athanases, S. Z., Sanchez, S. L., \& Martin, L. M. (2020). Saturate, situate, synthesize: Fostering preservice teachers' conceptual and practical knowledge for learning to lead class discussion. Teaching and Teacher Education, 88, 102970. https://doi.org/10.1016/j.tate.2019.102970.

Bdiwi, R., de Runz, C., Faiz, S., \& Cherif, A. A. (2019). Smart learning environment: Teacher's role in assessing classroom attention. Research in Learning Technology, 27, 1-14. https: //doi.org/10.25304/rlt.v27.2072.

Bressington, D. T., Wong, W. kit, Lam, K. K. C., \& Chien, W. T. (2018). Concept mapping to promote meaningful learning, help relate theory to practice and improve learning self-efficacy in Asian mental health 
nursing students: A mixed-methods pilot study. Nurse Education Today, 60(February 2017), 47-55. https: //doi.org/10.1016/j.nedt.2017.09.019.

Brown, C., Poortman, C., Gray, H., Ophoff, J. G., \& Wharf, M. M. (2021). Facilitating collaborative reflective inquiry amongst teachers: What do we currently know? International Journal of Educational Research, 105. https://doi.org/10.1016/j.ijer.2020.101695.

Carlucy, Suadnyana, \& Negara. (2018). Pengaruh Model Pembelajaran Inkuiri Terbimbing Berbantuan Media Konkret Terhadap Kompetensi Pengetahuan IPA. Mimbar Ilmu Undiksha, 23(2), 162-169. https: //doi.org/10.23887/mi.v23i2.16416.

Chai, C. S., \& Kong, S.-C. (2017). Professional learning for 21st century education. Journal of Computers in Education, 4(1), 1-4. https://doi.org/10.1007/s40692-016-0069-y.

Clay, V., König, P., Kühnberger, K.-U., \& Pipa, G. (2021). Learning sparse and meaningful representations through embodiment. Neural Networks, 134. https://doi.org/10.1016/j.neunet.2020.11.004.

Cooper, V. A., Forino, G., Kanjanabootra, S., \& Meding, J. von. (2020). Leveraging the community of inquiry framework to support web-based simulations in disaster studies. The Internet and Higher Education, 47. https://doi.org/10.1016/j.iheduc.2020.100757.

Dede Trie Kurniawan, \& Maryanti, S. (2018). Analysis of Math Teacher Candidates' Misconception on the Dynamic Electricity Concept. Scientiae Educatia: Jurnal Pendidikan Sains, $7(1)$. https: //doi.org/10.24235/sc.educatia.v7i1.2481.

Ertikanto, C., Herpratiwi, Yunarti, T., \& Saputra, A. (2017). Development and evaluation of a modelsupported scientific inquiry training program for elementary teachers in Indonesia. International Journal of Instruction, 10(3). https://doi.org/10.12973/iji.2017.1037a.

Fajarianingtyas, D. A., \& Yuniastri, R. (2015). Upaya reduksi miskonsepsi siswa pada konsep reaksi redoks melalui model guided inquiry di SMA Negeri I Sumenep. Jurnal Lentera Sains (Lensa), 5(1). https://doi.org/10.24929/lensa.v5i2.248.

Febriana, M., 'ari, H. A. A., Subali, B., \& Rusilowati, A. (2018). Penerapan model pembelajaran Inquiry Pictorial Riddle untuk meningkatkan keaktifan siswa. (JPFK), Jurnal Pendidikan Fisika Dan Keilmuan, 4(1). https://doi.org/10.25273/jpfk.v4i1.1879.

Fitriyati, I., \& Munzil, M. (2017). Penerapan Strategi Pembelajaran Inkuiri Terbimbing Berbantuan Media Untuk Meningkatkan Keterampilan Berpikir Ilmiah Siswa Pada Pembelajaran IPA SMP. Jurnal Penelitian Pendidikan IPA. https://doi.org/10.26740/jppipa.v1n1.p1-6.

Gunawan, Harjono, A., Hermansyah, \& Herayanti, L. (2019). Guided inquiry model through virtual laboratory to enhance students' science process skills on heat concept. Cakrawala Pendidikan, 38(2), 259-268. https://doi.org/10.21831/cp.v38i2.23345.

Hasan, S., Bagayoko, D., \& Kelley, E. L. (1999). Misconceptions and the certainty of response index (CRI). Phys. Educ, 34(5).

Husnaini, S. ., \& Chen, S. (2019). Effects of Guided Inquiry Virtual and Physical Laboratories on Conceptual Understanding, Inquiry Performance, Scientific Inquiry Self-Efficacy, and Enjoyment. Physical Review Physics Education Research, 15(101019), 16. https: //doi.org/10.1103/PhysRevPhysEducRes.15.010119.

Hwang, G. J., Wang, S. Y., \& Lai, C. L. (2020). Effects of a social regulation-based online learning framework on students' learning achievements and behaviors in mathematics. Computers and Education, 160, 104031. https://doi.org/10.1016/j.compedu.2020.104031.

Kohar, S., Jatmiko, B., \& Raharjo, R. (2017). Pengembangan perangkat pembelajaran berbasis inkuiri terbimbing menggunakan simulasi PhET untuk mereduksi miskonsepsi siswa. JPPS (Jurnal Penelitian Pendidikan Sains), 6(2). https://doi.org/10.26740/jpps.v6n2.p1289-1301.

Kuala, S. (2020). Implementation of Technology-based Guided Inquiry to Improve TPACK among Prospective Biology Teachers. International Journal of Instruction, 13(2), 33-44. https: //doi.org/10.29333/iji.2020.1323a.

Kusumah, R. G. T., Walid, A., Pitaloka, S., Dewi, P. S., \& Agustriana, N. (2020). Penerapan Metode Inquiry Untuk Meningkatkan Hasil Belajar Materi Penggolongan Hewan Di Kelas IV SD Seluma. Jurnal Pendidikan Matematika Dan IPA, 11(1), 142-153. https://doi.org/10.26418/jpmipa.v11i1.34708.

Laksana, D. N. L., Dasna, I. W., \& Degeng, I. N. S. (2019). The effects of inquiry-based learning and learning styles on primary school students' conceptual understanding in multimedia learning environment. Journal of Baltic Science Education, 1(1). https://doi.org/10.33225/jbse/19.18.51.

Leonard, N. C., \& Nwanekezi, A. U. (2018). Effects of Guided Inquiry and Task Hierarchy Analysis Model in Cooperative Learning Strategy on Chemistry Students' Performance in Imo State. European Scientific Journal, ESJ, 14(25), 54-62. https://doi.org/10.19044/esj.2018.v14n25p54.

Li, F.-Y., Hwang, G.-J., Chen, P.-Y., \& Lin, Y.-J. (2021). Effects of a concept mapping-based two-tier test strategy on students' digital game-based learning performances and behavioral patterns. Computers \& 
Education, 24. https://doi.org/10.1016/j.compedu.2021.104293.

Liu, Y., Bellibaş, M. Ş., \& Gümüş, S. (2020). The effect of instructional leadership and distributed leadership on teacher self-efficacy and job satisfaction: Mediating roles of supportive school culture and teacher collaboration. Educational Management Administration and Leadership, 1-24. https: //doi.org/10.1177/1741143220910438.

Margunayasa, I. G., Dantes, N., Marhaeni, A. A. I. N., \& Suastra, I. W. (2019). The Effect of Guided Inquiry Learning and Cognitive Style on Science Learning Achievement. International Journal of Instruction, 12(1), 737-750. https://doi.org/10.29333/iji.2019.12147a.

Meriana, T., Angelius Domes, A., -, Y., \& Sihotang, H. (2021). The Impact of the Covid-19 Pandemic on Students Behaviour During Online Learning at Pelangi Kasih Elementary School in Jakarta. Advances in Social Sciences Research Journal, 8(4), 594-604. https://doi.org/10.14738/assrj.84.10112.

Muliani, N. K. D., \& Wibawa, I. M. C. (2019). Pengaruh Model Pembelajaran Inkuiri Terbimbing Berbantuan Video Terhadap Hasil Belajar IPA. Jurnal Ilmiah Sekolah Dasar, 3(1), 107-114. https: //doi.org/10.31539/spej.v2i1.333.

Mursalin. (2014). Meminimalkan Miskonsepsi Pada Materi Rangkaian Listrik Dengan Pembelajaran PredictObserve-Explain. Jurnal Ilmu Pendidikan, 20(1). https://doi.org/10.17977/jip.v20i1.4383.

Mustika, A. A., Hala, Y., \& Arsal, A. F. (2015). Identifikasi Miskonsepsi Mahasiswa Biologi Universitas Negeri Makassar pada Konsep Genetika dengan Metode CRI. Sainsmat, 3(2). https: //doi.org/10.35580/sainsmat3211192014.

Negor, R. A., Hidayah, H., Subali, B., \& Rusilowati, A. (2018). Upaya Membangun Ketrampilan Berpikir Kritis Menggunakan Peta Konsep Untuk Mereduksi Miskonsepsi Fisika. JP (Jurnal Pendidikan), 3(1). https://doi.org/10.26740/jp.v3n1.p45-51.

Nurlaily, V. A., Soegiyanto, H., \& Usodo, B. (2019). Elementary school teacher's obstacles in the implementation of problem-based learning model in mathematics learning. Journal on Mathematics Education, 10(2), 229-238. https://doi.org/10.22342/jme.10.2.5386.229-238.

Nurmayani, L., Doyan, A., \& Sedijani, P. (2018). Pengaruh Model Pembelajaran Inkuiri Terbimbing Terhadap Hasil Belajar Fisika Peserta Didik. Jurnal Penelitian Pendidikan IPA. https://doi.org/10.29303/jppipa.v4i2.113.

Pratiwi, I., Suartama, I. K., \& Tegeh, I. M. (2016). Pengembangan E-Learning dengan Model Prototype Berorientasi Model Pembelajaran Inquiry Siswa Kelas VII SMPN 2 Negara. Jurnal Edutech Undiksha, 4, No 2. https://doi.org/10.23887/jeu.v4i2.7615.

Pratono, A., Sumarti, S. S., \& Wijayati, N. (2018). Contribution of Assisted Inquiry Model of E-Module to Students Science Process Skill. Journal of Innovative Science Education, 7(1), 62-68. https://doi.org/10.15294/jise.v7i1.20633.

Purwanita, Y., Riyanto, Y., \& Suyanto, T. (2019). The Influence of Multimedia Assisted Inquiry Learning Methods on My Heroes Theme of Critical Thinking Skills and Learning Outcomes of Class IV Students ofElementary School. International Journal of Scientific and Research Publications (IJSRP), 9(7), p9169. https://doi.org/10.29322/ijsrp.9.07.2019.p9169.

Rosidin, U., Kadaritna, N., \& Hasnunidah, N. (2019). Can argument-driven inquiry models have impact on critical thinking skills for students with differentpersonality types? Cakrawala Pendidikan. https://doi.org/10.21831/cp.v38i3.24725.

Ruqoyyah, R., Fatkhurrohman, M. A., \& Arfiani, Y. (2020). Implementasi Model Inkuiri Terbimbing Berbantuan Pop-up book untuk Meningkatkan Kemampuan Berpikir Kreatif Peserta Didik. JEMS: Jurnal Edukasi Matematika Dan Sains, 8(1), 42-48. https://doi.org/10.25273/jems.v8i1.6166.

Sadh, S., Tima, M. T., \& Cahyani, V. P. (2017). Analysis of acid-base misconceptions using modified certainty of response index (CRI) and diagnostic interview for different student levels cognitive. International Journal of Science and Applied Science, 1(2). https://doi.org/10.20961/ijsascs.v1i2.5126.

Santiasih, N. I., Marhaeni, A. A. I. N., \& Tika, I. N. (2013). Pengaruh Model Pembelajaran Inkuiri Terbimbing Terhadap Sikap Ilmiah dan Hasil Belajar IPA Siswa Kelas V SD No. 1 Kerobokan Kecamatan Kuta Utara Kabupaten Badung Tahun Pelajaran 2013/2014. Jurnal Pendidikan Dasar Ganesha, 3(1). https: //doi.org/10.23887/jet.v3i1.17959 Article Metrics.

Shrestha, S., \& Jose. (2014). Knowledge and practice of nursing ethics and laws. Journal of Universal Collage of Medical Sciences, 2(3). https://doi.org/10.3126/jucms.v2i3.11825.

Siagian, H., \& Simatupang, R. (2017). Pengaruh Model Pembelajaran Inkuiri Terbimbing Terintegrasi Animasi Flash Terhadap Hasil Belajar Siswa Pada Materi Pokok Fluida Dinamis. Jurnal Penelitian Bidang Pendidikan, 23(1), 47-54. https: //doi.org/10.24114/jpp.v23i1.10000.

Stellmacher, A., Ohlemann, S., Pfetsch, J., \& Ittel, A. (2020). Pre-service teacher career choice motivation: A 
comparison of vocational education and training teachers and comprehensive school teachers in Germany. International Journal for Research in Vocational Education and Training, 7(2), 214-236. https://doi.org/10.13152/IJRVET.7.2.5.

Stender, A., Schwichow, M., Zimmerman, C., \& Härtig, H. (2018). Making inquiry-based science learning visible: the influence of CVS and cognitive skills on content knowledge learning in guided inquiry. International Journal of Science Education, https: //doi.org/10.1080/09500693.2018.1504346.

Suparmi, N. W. (2019). Hasil Belajar Pemahaman Konsep Dan Berpikir Kreatif Siswa Dalam Pembelajaran Inkuiri Bebas Dan Inkuiri Terbimbing. Journal of Education Technology, 2(4), 192. https://doi.org/10.23887/jet.v2i4.16548.

Suryantari, N. M. A., Pudjawan, K., \& Wibawa, I. M. C. (2019). Pengaruh Model Pembelajaran Inkuiri Terbimbing Berbantuan Media Benda Konkret Terhadap Sikap Ilmiah dan Hasil Belajar IPA. International Journal of Elementary Education, 3(3), 316-326. https://doi.org/10.23887/ijee.v3i3.19445.

Tan, C. (2021). The impact of COVID-19 on student motivation, community of inquiry and learning performance. Asian Education and Development Studies, 10(2), 308-321. https://doi.org/10.1108/AEDS-05-2020-0084.

Taruh, E., Abbas, N., \& Umar, M. K. (2019). Studies The Influence Of Blended Learning-Based Guided Inquiry Learning Model And Self Efficacy On Students ' Scientific Literacy. European Journal Of Education, 1,137-150. https://doi.org/10.5281/zenodo.3445474.

Wahyuni, R., Hikmawati, H., \& Taufik, M. (2017). Pengaruh Model Pembelajaran Inkuiri Terbimbing dengan Metode Eksperimen terhadap Hasil Belajar Fisika Siswa Kelas XI IPA SMAN 2 Mataram Tahun Pelajaran 2016/2017. Jurnal Pendidikan Fisika Dan Teknologi, 2(4). https://doi.org/10.29303/jpft.v2i4.308.

Wahyuni, V. A., Surahman, E., \& Musthofa, R. F. (2019). Pengaruh Pembelajaran Guided Inquiry Terhadap Kemampuan Berpikir Kritis Dan Retensi Peserta Didik Pada Konsep Sistem Indera Manusia Studi Eksperimen di Kelas XI MIA MAN 1 Tasikmalaya Tahun Ajaran 2017/2018. Bioedusiana, 4(2). https: //doi.org/10.34289/292825.

Washington, G. Y. (2019). The Learning Management System Matters in Face-to-Face Higher Education Courses. Journal of Educational Technology Systems, 48(2), 255-275. https://doi.org/10.1177/0047239519874037.

Widarti, H. R., Permanasari, \& Mulyani, S. (2016). Student Misconception On Redox Titration (A Challenge On The Course Implementation Through Cognitive Dissonance Based On The Multiple Representations). Jurnal Pendidikan IPA Indonesia, 5(1). https://doi.org/10.15294/jpii.v5i1.5790.

Witanecahya, S. Z., \& Jatmiko, B. (2014). Penerapan Model Pembelajaran Inkuiri Terbimbing (Guided Inquiry) untuk Mengurangi Miskonsepsi Siswa Kelas X SMAN 2 Ponorogo pada Pokok Bahasan Perpindahan Panas. Jurnal Inovasi Pendidikan Fisika (JIPF), 3(3).

Yunitasari, I., Widarti, H. R., \& Nazriati, N. (2019). Miskonsepsi Asam Basa Berbasis Multipel Representasi pada Lintas Jenjang Pendidikan. Jurnal Pendidikan Teori, Penelitian, Dan Pengembangan, 4(12). https://doi.org/10.17977/jptpp.v4i12.13082. 